\title{
Reading 'blackface': A (narrative) introduction to Richard Kearney's notion of carnal hermeneutics
}

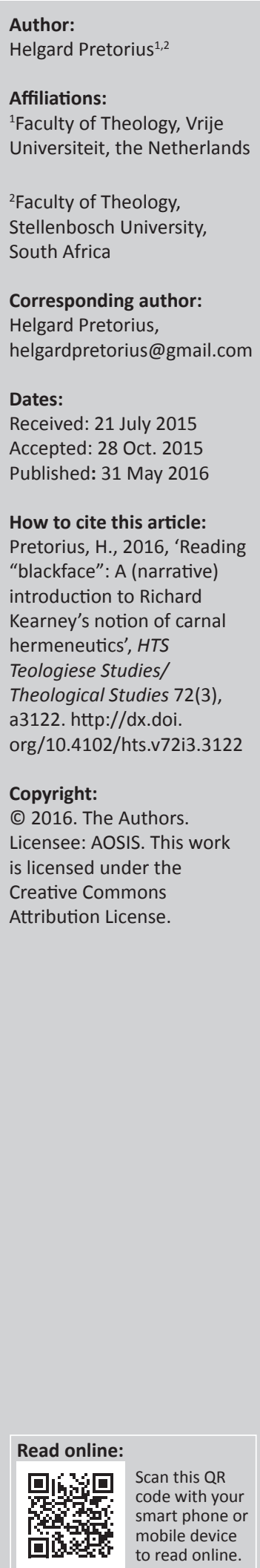

Author:

Affiliations:

${ }^{1}$ Faculty of Theology, Vrije

${ }^{2}$ Faculty of Theology,

Stellenbosch University,

South Africa

Corresponding author: Helgard Pretorius,

\section{Dates:}

Received: 21 July 2015

Accepted: 28 Oct. 2015

How to cite this article:

Pretorius, H., 2016, 'Reading

introduction to Richard

Kearney's notion of carnal

hermeneutics', HTS

Teologiese Studies/

Theological Studies 72(3),

a3122. http://dx.doi.

is licensed under the

Creative Commons

Attribution License.
Prominent Irish philosopher Richard Kearney's notion of 'carnal hermeneutics' is introduced by applying it to a case study of a recent event that took place at one of South Africa's university campuses. The narrative assists in illuminating some of the core principles of carnal hermeneutics and illustrates the applicability of carnal hermeneutics as a 'diagnostic caring for lived existence'. In the process, an analysis is also given of the event in question, which is connected to what has widely been labelled as 'blackface'. In conclusion, the contextual, philosophical, ethical, and theological implications of carnal hermeneutics are explored with an eye on theological praxes in South Africa today.

\section{Introduction}

\section{How do we sense, figure, and discern the other in our midst?}

It is in response to this enigmatic challenge that I would like to facilitate a dialogue with Richard Kearney's ${ }^{1}$ notion of 'carnal hermeneutics'. ${ }^{2}$ The question of otherness and the stranger has occupied Western thought and culture from its earliest beginnings. Yet it has most often been dealt with from a perspective that holds reason as superior, even divorced from bodily existence. By upholding 'pure reason' as the sovereign form of consciousness, embodied existence and fleshly sensation were subordinated to the 'noble' processes of the intellect and understanding. In contrast, Kearney seeks to restore this skewed view (that still haunts us today) by 'revisiting the deep and inextricable relationship between sensation and interpretation' (Kearney 2015:17). By thus restoring this relationship, carnal hermeneutics denotes a hermeneutic 'sense' that extends from the more traditional definition of 'deciphering cryptic messages' right down to the most primal, carnal forms of discernment (Kearney 2012:180). Without disregarding a traditional hermeneutics of meaning, carnal hermeneutics supplements the historical and existential with 'a sort of incarnate phronesis which sounds, probes, scents, and filters' (2012:180).

In his most recent essay on the topic, 'The Wager of Carnal Hermeneutics', Kearney returns (via Jean-Louis Chrétien, among others) to Aristotle's discussion of the senses in De Anima - and especially his treatment of 'touch' - to retrieve Aristotle's understanding of 'flesh as a medium, not an organ' (Kearney 2015:19-26). He then traces the further development of this basic insight via the phenomenological work of Husserl, Satre and Levinas to arrive at a fully-fledged phenomenology of the flesh in the work of Merleau-Ponty (Kearney 2015:26-46). By highlighting Merleau-Ponty's insight that sensation and interpretation inter-animate each other at the most fundamental level - that 'sensation is expression and expression is sensation', or that 'flesh is word and word is flesh' - Kearney finds a site at which to reopen a creative dialogue between a phenomenology of the flesh and a hermeneutics of existence (2015:45-46). It is at this juncture that he turns to the last chapter of Paul Ricoeur's Oneself as Another (1990), entitled 'Selfhood and

1.Richard Kearney currently holds the Charles B. Seelig chair of Philosophy at Boston College, USA. Originally from Ireland, where he held a professorship in Dublin, Kearney is widely recognised for his work on imagination, Irish/world politics and literature, and the philosophy of Paul Ricoeur, but more recently also the so-called continental turn to religion. For an introduction to Kearney's oeuvre see Pretorius, HM, Theology at the Limit: an investigation of Richard Kearney's philosophical hermeneutics in search of a responsible theological hermeneutic (2015).

2.The notion of 'carnal hermeneutics' emerges as a vital element in Kearney's encompassing project of developing what he calls a diacritical hermeneutics. Diacritical hermeneutics in turn emerges from the challenge of alterity or otherness and the enduring need for phronetic discernment in encounters with strangers. It is not without reason that Kearney's first sketch of diacritical hermeneutics appears in his fine work on alterity, Strangers, Gods, and Monsters: Interpreting Otherness (2003a - see in particular chapters 3-5 and 7). While earlier sketches of carnal hermeneutics also featured in Anatheism: Returning to God after God (2010b; see chapters 1-2, 5), a much more comprehensive, systematic discussion of carnal hermeneutics by Kearney can be found in the opening chapters of the collection of essays by that very name: Carnal Hermeneutics, Richard Kearney \& Brian Treanor (Eds.), Fordham University Press: New York (2015). This impressive volume includes contributions by some of the major contemporary voices in the conversation: Jean-Luc Nancy, Jean-Louis Chrétien, Julia Kristeva, Michel Henry, Jean-Luc Marion, and Paul Ricoeur.

Note: Helgard Pretorius is a Ph.D. Candidate at Stellenbosch University \& Vrije Universiteit Amsterdam and Research \& Teaching Assistant at Stellenbosch University. 
Otherness' in order to complete the turn through a carnal phenomenology towards a carnal hermeneutics capable of accommodating the paradox of 'oneself as another' (2015:4655). In doing so, the creative tension between recognising the other as another (semblable) and respecting the transcendence of the other as Other is maintained (2015:50-55).

Because Kearney has already provided helpful essays introducing the notion of carnal hermeneutics in a systematic fashion, the concept will be approached here from the perspective of experience: by presenting a case study from my own context. In doing so I hope to do two things: firstly, in recounting my story I wish to identify and illustrate some of the main tenets of carnal hermeneutics: to give a narrative introduction to carnal hermeneutics, so to speak. Secondly, by facilitating a dialogue between carnal hermeneutics and a very particular event I hope to illustrate something of the relevance and applicability of carnal hermeneutics. The goal is to offer at the very least a preliminary diagnosis of what transpired at the incident in question, wagering on Kearney's claim that carnal hermeneutics has 'a diagnostic role' to play 'as a caring for lived existence' (Kearney 2011:9).

\section{The case study: White flesh, shoe polish and black flesh}

In 2014 two incidents occurred at two of the most celebrated universities in South Africa, causing a stir in the media and on various social media platforms. In both cases, white university students painted their bodies black for dress-up parties and in both cases photos of them went viral on social media platforms, Facebook and Twitter. The photos caused outrage across the country, but particularly among black students of the universities in question. The perpetrators were accused of taking part in 'blackface', a phenomenon dating back to the minstrel shows of the 1800s in the United States in which white actors would paint their bodies black to play the role of black characters to mocking, caricatured effect. ${ }^{3}$

At the first incident at the University of Pretoria, two white female students painted their bodies black and dressed up as domestic workers. Disciplinary action by the university ended in the students being expelled from their university residences. Dismay ensued when, not more than 2 weeks after this incident, two white male students from the University of Stellenbosch also donned blackface for a dress-up party to be held at a restaurant in a township on the

\footnotetext{
3.The history of blackface is too long and rich to relate here, but let it suffice to say that it is a powerful expression of the social imaginaries at work in white, colonial histories of the 19th century and 20th century - and that this imaginary continue to resurface in societies to this day. The recent Zwarte Piet debates in the Netherlands are a case in point. For a useful website on the history of blackface see http://black-face.com/. For a useful website on the history of Zwarte Piet see http:// www.stnicholascenter.org/pages/zwarte-piet/. Recent research by South African musicologist, Willemien Froneman has also revealed the extensive role that musicologist, Wilemien froneman has also revealed the extensive role that minstrelsy played in South Africa, especially in the formation of Afrikaner culture. See Froneman's unpublished PhD thesis: 'Pleasure Beyond the Call of Duty: Perspectives, Retrospectives and Speculations on Boeremusiek' (Froneman 2012) See also Kearney's On stories (2002) for an analysis of unconscious social imaginarie of othering in the American psyche as these find expression in film - in particular, the premiere of D.W. Griffith's Birth of a nation (1915) where the issue of race is prominent.
}

outskirts of the lush, historical town of Stellenbosch. ${ }^{4}$ Once again photos were taken and these circulated like wildfire, causing outrage and stimulating debate across the country.

The student and disciplinary councils of Stellenbosch University responded quickly and pro-actively. An ad hoc forum of student leaders from across campus was established to engage the three students involved in conversations. One of the outcomes of these conversations was that the perpetrators formulated a public response that included an apology and a pledge of redress.

At a Student Parliament meeting held on 7 October 2014 on the Stellenbosch University campus the young men had the opportunity to present themselves publicly. Student parliament meetings had not been well attended in 2014, but on that particular evening, a great number of students were in attendance, including a larger-than-usual amount of black students. The atmosphere was emotionally charged and tense. The speaker of the house called for order a number of times and felt obliged to mention the presence of campus security.

At last, the moment arrived that most seemed to be waiting for: the 'blackface trio', as they became known came forward to express their public statements. ${ }^{5}$ Solemn faced and nervous, each of them took a step forward as their turn came and read their statements. They expressed remorse at what they had done, saying: 'We want to express our deepest and sincerest apologies for the hurt that we caused' (Coetzee 2014:3). They admitted that they were ignorant of the gravity of their actions and of the painful effects it would have on others.

We know that there are people who support our actions, but we ask that they reconsider their opinions, because we have come to realise that there is no justification for our actions. (Coetzee 2014:3)

It seemed clear that they had come some way from their initial responses on social media (in which they tried to justify their actions in the name of innocent fun) (Coetzee 2014:3). They now acknowledged their embeddedness and complicity in a racialised society: 'By painting our bodies black, we have reminded people of the traumatic past which was experienced throughout our country's dark history', (Coetzee 2014:3) and they recognised that the incident was not an isolated event, but that it 'has brought to light the underlying racial issues that still exist within Stellenbosch' (Coetzee 2014:3).

Finally, the trio pledged not to leave the matter where it stood; to engage themselves in processes of reconciliation on campus; to go back to their own high schools where they

4. The word 'township' is a loaded term, and yet is such an important part of SouthAfrican realities that one cannot avoid using it. To be brief, townships are urban living areas, most of which were established in the apartheid times of racia living areas, most of which they were reserved for black people and mixed-raced segreg ion dixed-raced people. Built on the peripheries of towns and cities, they often lack the quality of infrastructure found in urban centres and sometimes include large informal
settlements.

5.The 'trio' included the friend who, after photographing the two dressed-up men, posted it on social media platforms. 
would share their story with pupils in an attempt to educate them about what they called the sheltered ignorance of white privilege.

Then came the responses. The first among them came from a black student who applauded the speakers for their courage to appear in person, adding that he could see the sincerity of their apologies. He then remarked that he was not interested in revenge, but greater inclusivity and understanding on campus (to which the greater majority of the crowd irrupted in applause and approval). It seemed to me at this point as if the majority of the crowd perceived the perpetrators' statements as sincere.

However, this was not the last word. Statements were heard about personal offense suffered, but also about how the incident caused serious damage to processes of transformation at the university, not to mention the university's image. Many questions were directed at the perpetrators, asking them about their thought processes during the incident and about how they will make amends for their actions. There were some who, for various reasons, remained unconvinced by their public statements and there were others who held even stronger positions: who felt that justice had not been served, that the real questions had not yet been addressed, that healing could not yet begin.

\section{In these matters, matter matters}

How should one understand these matters?

Certainly, these are matters of interpretation. Multiple, conflicting interpretations are possible, each involving complex interactions between pre-understandings, contexts, and histories of interpretation. An event such as this exposes both the possibilities and impossibilities of horizons fusing with one another. And yet, although such a task seems well suited for hermeneutics, only a hermeneutics that is sufficiently carnal will do. For these are matters of intimate flesh and public bodies: bodies understood and misunderstood, vulnerable and strong; bodies divided and separated, painted and unpainted; bodies bearing wounds, anger, remorse, and regret. It is about bodies digitalised and disseminated, implaced and displaced, welcomed and rejected, regarded and disregarded. These are matters of flesh exposed to flesh, flesh calling and responding to flesh. In these matters, matter matters. And therefore these are indeed matters for a carnal hermeneutics.

\section{Blackface as an attack on black flesh}

Drawing in particular on Merleau-Ponty's phenomenology of the flesh and Paul Ricoeur's hermeneutic phenomenology of the person, Kearney's notion of carnal hermeneutics rediscovers 'the flesh as a mediation, a hyphen, a crossing' between the self and the other that precedes all divisions between subject and object (Kearney 2015:28). ${ }^{6}$ In other words, flesh is human existence as it finds itself immersed in

6.In The Visible and the Invisible, [Merleau-Ponty] defines flesh accordingly as a "chiasm" between me and the world-a reversible crossing that precedes all analytic and transcendental divisions between subject and object, consciousness and thing' (Kearney 2015:37). and exposed to the world; a world which includes others, other bodies - each existing as another flesh. This means that existence as flesh is a 'double gesture of action-passion' (Kearney 2015:28). ${ }^{7}$

Prior to my role as active subject, which my sense of sight so powerfully evokes, flesh 'first opens me to a radical passivity and passion - $[a]$ naked exposition to the other-than-me, receptive to whomever and whatever exceeds and calls and gives itself to me' (Kearney 2015:27). Here our sense of touch, not sight, is the operative sense, the foundation of all other senses, for it 'inserts me - body and soul - into the flesh of the world' (Kearney 2015:28).

Without a doubt my flesh is my vulnerability, my passion, my wound (Kearney 2015:27). My flesh reveals a radical interdependency in which my creative possibilities of projecting meaning onto others cannot be divorced from simultaneously receiving meaning from others. In the flesh - exemplified by the 'double sensation' of touching one's own body - one's agency (the capacity to touch) and one's passivity (the possibility of being touched), one's action and one's passion, are radically intertwined (Kearney 2015:27-28).

We have struck here on Merleau-Ponty's important definition of flesh as 'chiasm' - a criss-crossing between me and the world, but also between all my senses (Kearney 2015:23). Seeing implies being seen, but also being tangible. Flesh is such a cross-referencing of sight and touch and taste and smell and also hearing. And here comes the central and most profound insight of carnal hermeneutics: that 'this chiasmic function is extended not only to all the senses but to language itself. The I that speaks words is the I spoken in words' (Kearney 2015:38). By pointing out the reversibility of linguistic sense and perceptual sense, Merleau-Ponty's phenomenology of sensation is brought 'to the threshold of hermeneutics' (Kearney 2015:38). ${ }^{8}$

This, I believe is essential for coming to some understanding of the 'blackface' phenomenon in South Africa.

We begin in the flesh, with the fact that for many black people perceiving white bodies painted black (in most cases) is experienced (in varying degrees) as an attack on black flesh.

But, how could this be? Surely this was never the intention of the students participating in the act? Surely their intentions should count for something? These are questions often raised by white spectators. But such a perspective prioritises the

7.In this regard Kearney's discussion of Ricoeur is particularly illuminating as it seeks to break through the supposed dichotomy between intimate flesh and public body (Kearney 2015:50-55) restoring it hermeneutically as paradox. In doing so Ricoeur developed Husserl's revolutionary insight that 'my perception of others accompanies my perception of self' (Kearney 2015:27) 8.See especially the following quote from Merleau-Ponty's The Visible and The
Invisible (VI, 155-my italics): 'The same fundamental phenomenon of reversibility Invisible (VI, $155-$ my italics): 'The same fundamental phenomenon of reversibility
which sustains both the mute perception and the speech... manifests itself by an which sustains both the mute perception and the speech ... manifests itself by an
almost carnal existence of the idea, as well as by a sublimation of the flesh' (Kearney 2015:38). 
intimacy of flesh for me at the expense of the public character of one's body for others. It fails to acknowledge, as Ricoeur says in Fallible Man (1986), that:

my body is implicated as a power in the instrumentality of the world, in the practicable aspects of this world that my action furrows through, in the products of work and art. (cited in Kearney 2011:11)

Such involvement in the world means that one needs to be conscious of 'both an intimate body for me (Leib) and a physical natural body among other bodies (Korper)' in order to empathise with the other (Kearney 2015:53). Furthermore, once these bodies are photographed, they become objectified as text; and hermeneutics teaches us that the text as text transcends the finite conditions of the original speech situation, or in this case 'dress-up party'. The photo as text becomes severed from the 'original intentions' of the author, or in this case the 'party-goer', opening it up to a plurality of possible interpretations far exceeding the experiences and imaginings of the tactless student.

As a white male person participating in these events, I am compelled to try and imagine the criss-crossing and crossreferencing that takes place as a black person perceives such a photo.

A carnal hermeneutic approach helps me to understand that being black in South Africa today means more than bearing a black skin. It is to embody memories - memories of a time in which the blackness or whiteness of one's body defined one's entire existence - including personal, social, cultural, political, and religious realities. With a sickening precision, black and white bodies were separated, classified and where deemed necessary, torn apart. White bodies stood, privileged and preserved, on one side of the capricious line, while black bodies bore the drudgery on the other side - disempowered, stereotyped, silenced. Apartheid ended 22 years ago, but its legacy persists. To the extent that South Africa remains a deeply racialised and unequal society, embodied traumas include the present perfect tense, which of course means that the realities of being black often include the anticipation of further scorn.

To be in the flesh is to have memories as wounds, and wounds as embodied memories. Or to use Michel Foucault's phrase, it is to bear 'the stigmata of past experiences' on one's body (cited in Ackermann 2003:69). And so, even the simplest perception, such as seeing a photo on social media of white bodies painted black, is shot through, from beginning to end, with memories and stories (stories heard, told, and suppressed). Perception is already laced with powerful emotions, values, desires, and anticipations. It is in this sense of flesh as chiasm - as the intertwining of meaning and matter, body and soul, memory and muscle - that black flesh comes under attack. Powerful examples of this can be found in Franz Fanon's dramaturgical reflections, which provide poignant accounts of the violence involved when a 'historicoracial schema' replaces the normal bodily schema under 'the white man's eyes', causing a radical estrangement from one's own body. ${ }^{9}$

As a white person participating in these events, I am not only moved to imagine the lived experience of black people. I am equally called to critical self-examination. The detour of black experience makes a return to scrutinise white flesh all the more urgent. Carnal hermeneutics also helps us to consider the inability of most white bodies to register the offense and violence of such actions.

Surveying some responses by whites to these events, many openly confess that they do not understand what all the fuss is about. Even whites who condemn blackface often cannot provide an adequate reason for doing so. At best they will refer to its political incorrectness, or point out the idiocy of donning blackface 2 weeks after it caused such public outrage elsewhere. A common response goes: 'if I want to dress up like Ginger Spice, I'll wear a red wig, if I want to dress up like Serena Williams, I'll wear a black skin and an afro'. However, it is partly this nonchalance with which whites want to cross the skin barrier that so offends. A crossing without understanding: tactlessly bearing a black skin without any sense of what it means tangibly to be black. More generally, these perspectives illustrate just how deeply rooted the dualism between matter and meaning has become for us. For is it not only once we rediscover the flesh as chiasm that the embodied meaning of blackface dawns on us?

It is clear that my white flesh is equally laced with powerful memories, emotions, values, presumptions, fears, and desires. My white flesh is partly the product of a history that has done its utmost to prevent and pre-empt exposure to black flesh. And so, I must admit that I am out of touch with the realities faced by black bodies. At least, this is where I begin.

9.See for example Fanon's Black Skin, White Masks (1967): And then the occasion arose when I had to meet the white man's eyes. An unfamiliar weight burdened me. The real world challenged my claims. In the white world the man of color encounters difficulties in the development of his bodily schema. Consciousness of the body is solely a negating activity. It is a third-person consciousness. The body is surrounded by an atmosphere of certain uncertainty.... (Fanon 1967:83)

Below the corporeal schema I had sketched a historico-racial schema. The elements that I used had been provided for me not by 'residual sensations and perceptions primarily of a tactile, vestibular, kinesthetic, and visual character,' but by the other, the white man, who had woven me out of a thousand details, anecdotes, stories. I thought that what I had in hand was to construct a physiological self, to balance space, to localize sensations, and here I was called on physiological self, to balance space, to localize sensations, and here I was called on for more. 'Look, a Negro!' It was an external stimulus that flicked over me as passed by. I made a tight smile. 'Look, a Negro!' It was true. It amused me. 'Look, a Negro!' The circle was drawing a bit tighter. I made no secret of my amusement. 'Mama, see the Negro! I'm frightened!' Frightened! Frightened! Now they were beginning to be afraid of me. I made up my mind to laugh myself to tears, but laughter had become impossible. I could no longer laugh, because I already knew that there were legends, stories, history, and above all historicity... Then, assailed at various points, the corporeal schema crumbled, its place taken by a racia epidermal schema. In the train it was no longer a question of being aware of my body in the third person but in a triple person. In the train I was given not one but two, three places. I had already stopped being amused. It was not that I was finding febrile coordinates in the world. I existed triply: I occupied space. I moved toward the other... and the evanescent other, hostile but not opaque, transparent, not there, disappeared. Nausea.... (Fanon 1967:84)

I was responsible at the same time for my body, for my race, for my ancestors. I subjected myself to an objective examination, I discovered my blackness, my ethnic characteristics; and I was battered down by tom-toms, cannibalism, intellectual deficiency, fetishism, racial defects, slave-ships, and above all else, intellectual deficiency, fetishism, racial defects, slave-ships, and above all else,
above all: Sho' good eatin'... Where shall I hide? ... My body was given back to me sprawled out, distorted, recolored, clad in mourning in that white winter day. me sprawled out, distorted, recolored, clad in mourning in that white winter day.
The Negro is an animal, the Negro is bad, the Negro is mean, the Negro is ugly... (Fanon 1967:84-86) 


\section{'Go and dig deeper!'}

Does this mean black and white bodies are forever bound to their own interpretative frames, incapable of ever crossing the racial divide? Does flesh as chiasm ultimately result in a chasm effectively separating flesh from flesh?

Perhaps if we were speaking of a carnal phenomenology in the strictest sense, this might have been our fate. However, a carnal hermeneutics reminds us that sensing, figuring, and deciphering is always incomplete. Perception does not reach its proper end in the isolated individual but, as Kearney reminds us, continues to spiral up and down, from sensation to sense and back again. Interpreting and understanding is an open ended task, always to be taken up again, anew. Or as Merleau-Ponty says: the carnal existence of the idea is accompanied by the sublimation of the flesh..$^{10}$ This means that our deepest, carnal sensations are not incapable of being figured and trans-figured - both for ourselves and by others. They are not exempt from being reflected on in dialogue critically, sensibly, responsibly. Just as our loftiest abstractions ultimately have their roots in lived, bodily existence, our most carnal sensations yearn to come to terms with the other. ${ }^{11}$

In this regard, the Student Parliament event, as a continuation of the open-ended process of understanding, might be read as a sign of hope. Here again carnal hermeneutics provides us with language to help make sense of what transpired there.

The first aspect we might pick up on is the fact that the perpetrators appeared in person to make their public statements. This made all the difference; especially if one recalls Kearney's claim that the I that speaks words is the I spoken in words. In a sense, by presenting themselves at the Student Parliament meeting; by appearing before their fellow students whom they had offended, they were giving more than a statement-they gave themselves. ${ }^{12}$ Neatly trimmed as their statements were, their delivery said it all: regret could be spotted in the sinking slant of their eyes, nerves were unmistakable in their unstable hands, doubt present in the crack of their voices.

Of crucial importance here is Merleau-Ponty's discovery that it is specifically as corporeal, animate, and animal bodies that

\section{See note 8 above.}

11. Here, in turn, Fanon's humanist passion gives profound expression to the capacity to transfigure and transcend the estrangement caused by the given racial schema: On that day, completely dislocated, unable to be abroad with the other, the white man, who unmercifully imprisoned me, I took myself far off from my own presence, far indeed, and made myself an object. What else could it be for me but an
amputation, an excision, a hemorrhage that spattered my whole body with black blood? But I did not want this revision, this thematization. All I wanted was to be a man among other men. I wanted to come lithe and young into a world that was ours and to help to build it together. (Fanon 1967:85 - my italics)

Then, in the concluding lines of Black Skin, White Masks (1967:180-181) this passion is expressed as a manifesto of sorts, indeed, a prayer:

It is through the effort to recapture the self and to scrutinize the self, it is through the lasting tension of their freedom that men will be able to create the idea conditions of existence for a human world. Superiority? Inferiority? Why not the quite simple attempt to touch the other, to feel the other, to explain the other to myself? (my italics) Was my freedom not given to me then in order to build the world of the You? At the conclusion of this study, I want the world to recognize, with me, the open door of every consciousness (my italics.)

My final prayer:

o my body, make of me always a man who questions!

12.The emphasis on embodiment in carnal hermeneutics does not detract from the crucial role of narrative and narrative catharsis in such encounters between strangers (see Kearney 2003b, 2010b, 2013). we are capable (and in some cases incapable) of recognising our human self in the other - but then always: 'across difference ...: an identification not of identical beings, but of similar beings despite an infinite multiplicity of variation in corporeal form and of conduct across time' (see Kearney \& Semonovitch 2011b:16). Quoting Merleau-Ponty, Kearney and Semonovitch (2011b) say:

The very fact that we are oriented to display for others affirms the otherness of others. When I am talking with someone else, 'should the voice alter, should the unwonted appear in the score of the dialogue' - in short, if the person with whom I am speaking does anything that shows her to be alive and not a robot - then, 'suddenly there breaks forth the evidence that yonder also, minute by minute, life is being lived'. (p. 16)

This applies without any doubt to our case study, where the presence of the perpetrators in making their statement and the attentively listening audience 'provided evidence that yonder also ... life is being lived'. This is vital for the discovery - not just of the other as 'other' - but of oneself as another. It suggests that there may be times, circumstances, occasions that the physical presence of one-to-the-other is a necessary condition for authentic encounters between strangers or between estranged neighbours. Would something not have been irrevocably lost if the trio's statement had not been given in person, but published in the local newspaper or posted on the internet instead?

As mentioned above, the majority of the listeners responded positively to the public statement; and yet there were many who remained unconvinced or unsatisfied by the trio's repentance. How does one deal with such a plurality and even conflict of interpretations? A carnal hermeneutic approach begins by acknowledging that such an encounter is infinitely rich in significance; that it contains a surplus of possible, plausible meanings. If some did not accept the apology, one must begin by taking that experience seriously, recognising that it is as valid as any other interpretation. Indeed, no neutral, objective interpretation exists. ${ }^{13}$

As I recall what happened that night, the smaller group of students who did not accept the public apology were sitting together. One woman in particular, sitting among them, made an impression on me from the moment she entered the room. She was wearing colourful, traditional clothing and a striking yellow, red, and green headdress. She had paint meticulously applied to her face in a traditional style. During the questioning period she rose and made an emotional speech. She was from Kayamandi, the township where the blackface event occurred. It seemed to me that for her the real issues had not yet been addressed, that the damage done was larger than what was being accounted for, that justice was not yet on the horizon.

13.This implies that my own narration of how the event unfolded is already deeply marked by my prejudices, commitments and embodied experience. Other marked by my prejudices, commitments and embodied experience. Other
narrations are not only possible, but necessary - at every turn my observations potentially invite a critical response. 
'Place' played an important role in her discourse. ${ }^{14}$ These white men had invaded her community. They had the audacity to carry their painted bodies from their comfortable university residence in central Stellenbosch to Kayamandi an act of disrespect. She continued, 'do you know what it means for us to cross from Kayamandi into Stellenbosch on a daily basis to come to class?' Although she is proud to be a student at Stellenbosch University it was clear that she experiences campus as a hostile environment. 'How am I supposed to tell high school children in my community that they should come study at Stellenbosch, that they are welcome here, when you entered our place with such disrespect?'15

Eventually her passion got the better of her and she could not articulate her words clearly. She was asked to sit down by the speaker of the house. Words may have faltered, but her message was clear enough.

If I may wager a reading here, I would say that the main difference between her refusal and the affirmative response offered by other black students, is the following: For her the blackface event not only exposed wounds from a traumatic past, but rubbed salt into wounds that were still open. Her concern was with current injustices: injustices that she and her community still bore in their bodies on a daily basis. There is a profound injustice in prospective students from her community opting to study at remote (more hospitable) universities when a world-class institution exists on their doorstep. One could say that, for her, the blackface attack was intensified by a burning sense of injustice, deep frustration with the tardiness of transformation processes, and the experience of feeling like a stranger on her own university campus - the place she should be feeling at home. Before healing can begin, justice must take place.

The last word of the questioning session went to a black student in the back row. She first applauded the trio for their honesty and their intentions to educate others on the matter. 'However', she then said, 'I do not believe that you understand what blackface means yet. Go and dig deeper'. Her words epitomise hermeneutics, also a carnal hermeneutics, not as a method to be replicated, but as a virtue - an art to be cultivated. We are reminded of Schleiermacher's important insight that interpreting is not simply about overcoming or preventing misunderstandings. Instead, we are shown that all understanding is and remains mis-understanding. Our last speaker stands within a formidable hermeneutic tradition when she reminded us all that understanding begins with the acknowledgement that one does not understand.

'Go and dig deeper! I don't believe you understand yet'. The conversation is far from complete; understanding is

14. Here the phenomenological work done on "place," "the stranger" and "hospitality by among others, Edward Casey, Brian Treanor and David Wood could make a significant contribution. All three of these think and David Wood could make significant contributio Stranger (2011a).

15.Quotes in this paragraph are my paraphrases from memory. As far as I know no record exists of her speech. possible..., but not yet. Go and dig deeper! Like Fanon's prayer, ${ }^{16}$ these are words of protest; and for those with ears to hear it: words of hope. ${ }^{17}$

\section{Carnal hermeneutics and theological praxis in South Africa today?}

In conclusion, some brief remarks on the implications that carnal hermeneutics might have for theological praxis in South Africa today. These can be divided into four interconnected sets of questions: contextual, philosophical, ethical, and theological.

The very particular event invoked here to introduce Kearney's notion of carnal hermeneutics should not blind us to its relevance for other, broader contextual challenges facing South African society. Take one step back and it immediately becomes clear that these events were not isolated happenings, but that they form part of developments that have recently marked university campuses across the country. Consider the \#RhodesMustFall, \#OpenStellenbosch, and \#FeesMustFall movements. Take two steps back and broader questions of race, ethnicity, gender, sexuality, xenophobia, language, and identity politics also come into view. How might a carnal hermeneutics help us read between the lines of what is taking place in these highly contested conversations?

Kearney (2011) concludes his article, 'What Is Diacritical Hermeneutics?' with the following words:

To say that understanding is incarnate is to say that it answers to the life of suffering and action. Its application to human embodiment is its original and ultimate end. And here we return to its diagnostic role as a caring for lived existence - a listening to the pulse of suffering and solicitation between one human being and another. And, at times, between human being and that which precedes and exceeds it. It is in the passages 'between' that the dia of dia-critical takes on its full meaning. Diagnosis calls for endless dialogue: between disciplines, between text and action, between word and flesh, and above all between human persons who give and receive wisdom, attention, and healing. (p. 9)

With both its roots and ends in the embodied world of suffering and action, carnal hermeneutics promises to be a useful dialogue partner or diagnostic friend for contextual theologies (or context-sensitive theologians) that seek to address the many challenges mentioned above.

Alongside these contextual issues, carnal hermeneutics also makes a contribution to broader philosophical or theoretical discourses. Of course, a renewed interest in corporeal reality and embodiment has not had to wait for carnal hermeneutics to arrive on the scene. Many disciplines, from psychology to neuroscience, philosophy to sociology and linguistics to 16.See note 11 above.

17. Here it is significant to note that Paul Ricoeur ends his last major work, Memory, History, Forgetting (2004) with the word: incompletion - presenting the ever unfinished character of human life and history as a sign of hope and not despair. 
theology have all drawn richly from what could be called the corporeal turn. ${ }^{18}$ Carnal Hermeneutics' most important contribution to these discourses is arguably the creative way in which it intersects a phenomenology of the flesh with hermeneutic philosophy. In the South African theological scene, in which hermeneutic theory has come to inhabit a privileged place over the past 40 years, not least through the pioneering work of people like Bernard Lategan and many others, this means that the sensorial, embodied, affective, material, mediated and personal character of all interpretation and understanding be rediscovered and further developed. ${ }^{19}$

Behind the previous comments lies the assumption that carnal hermeneutics has a contribution to make to ethical considerations. As Terry Eagleton's recent study of ethics suggests, one could view the entire ethical enterprise as one that is animated by the 'trouble' we have with 'strangers' (see Eagleton 2008). Indeed, with the stranger, our best ethical theories are brought to the limit. Furthermore, if we are truly attentive we soon recognise that even our most familiar neighbours or closest kin are stranger than we would like to believe. Even more radically, psychoanalytic theorists like Julia Kristeva suggest that we are Strangers to Ourselves (see Kristeva 1991).

Against this background it is significant that Kearney's carnal hermeneutics emerges as he struggles with the challenge of alterity and the stranger. In responding to our opening question, 'how do we sense, figure, and decipher the other in our midst', carnal hermeneutics stands in service of ethics and has profound implications for wide-ranging ethical considerations, from sexuality to war, care to hospitality, human dignity to ecology $y^{20}$ - especially as these classic themes are transformed in an ever more globalised and digitalised world. ${ }^{21}$

Alongside the analytical merits of a carnal hermeneutic reflection on ethical questions, Kearney clears a space where a carnal hermeneutic may be at service to virtue ethics. If one of the classical virtues is sapientia (wisdom), Kearney (2015)

18.See the unpublished PhD thesis of Jacob Meiring entitled Theology in the Flesh: exploring the corporeal turn from a southern African perspective (2014), especially
Chapter 1 on the corporeal turn in interdisciplinary perspective and Chapter 4 on the corporeal turn in theology. It is significant that Meiring defines his own project as participating in a corporeal-linguistic turn, thus affirming carnal hermeneutics' as participating in a corporeal-linguistic turn, thus affirming carnal hermeneutics
claim that linguistic sense and corporeal sensation interanimate each other at a flaim that linguistic

19.For the central role of hermeneutics as a multivalent site of struggle in South Africa during the apartheid years - but still today - see Dirkie Smit's essay, On Bernard Lategan: Interpretation matters - An introduction (2013). See also the upcoming collection of Lategan's essays to be published later in 2015 by SUN Press under the title Hermeneutics and Social Transformation.

20.For ecological developments from a carnal hermeneutic approach see the contributions to Carnal hermeneutics (2015) by Brian Treanor (Mind the Gap: the Challenge of Matter, 57-73) and Ted Toadvine (Biodiversity and the Diacritics of Life, 235-248); as well as the collection of essays edited by Brian Treanor et al., Interpreting Nature: The Emerging Field of Environmental Hermeneutics (2013).

21. Kearney recognises the ever 'increasing digitalization of the body and virtualisation of our means of communication and communion' as a major (ethical) challenge in what he sees as 'our age of excarnation'. This will hopefully be addressed in his forthcoming volume: Flesh: Recovering our Senses in an Age be addressed in his forthcoming volume: Flesh: Recovering our Senses in an Age
of Excarnation. See his opinion piece, 'Losing our Touch', in the New York Times. reminds us of its etymological root: sapere (to taste), suggesting that...:

...our deepest knowing is tasting and touching. We first sound the world through the tips of our tongues, discerning between hot and cold, savoury and unsavoury (sic), course and smooth. Living well is a matter of 'savvy,' as we say. Ordinary language knows this, and philosophical language is no more than an extrapolation of what we already know 'deep down.' Wisdom, in the end, is tact. That is what we mean, isn't it, when we say that someone sensible is someone sensitive: they have 'the touch,' as healer, teacher, artist, lover... They are attentive, tentative, in touch with things. They get it. To have the right touch is to touch and be touched wisely. Touching well is living well. (p. 16)

An ethics of touch does not wish to compete with a Christian ethic of 'seeing things differently'. ${ }^{22}$ To the contrary, it wants to emphasise the chiastic interplay between the senses to argue that 'seeing things differently' is only made possible by listening attentively to the Word of the living God (see Smit 2007:446-448) - but also to 'the other', that is, to 'the strangeness, the particularity, and legitimate claims of the other' (Fouché \& Smit 1996:90) and so possibly acquiring 'a taste for the other'. ${ }^{23}$ Here a carnal hermeneutics will add that we learn to see things differently by 'touching', 'tasting' and 'being touched' (as in the sacraments). This calls for what Kearney calls a 'more refined sensibility of touch' not only greater sensitivity to the pathos of the other, but wisdom as the capacity to engage in the critical task of discriminating 'tactfully ... between Eros and Thanatos, between what brings life and what brings death' (Kearney 2015:22). ${ }^{24}$

Carnal hermeneutics teaches us that understanding is not in the first place about information, but about the formation of virtue and character. It is about the transformation of persons and communities. This was also revealed in our case study, in which the positive outcome was not signified by a resolution of terms or harmonious agreement between parties, but by the continuing process of transformation, initiated and stimulated by the physical encounter of one to another. Carnal hermeneutics is therefore not only concerned with the teleological question of defining good taste and touch, but also with the question of how persons are shaped in

22.'Seeing things differently', the title of a collection of John de Gruchy's sermons is considered by Dirkie Smit as a core theme in de Gruchy's and many other contemporary Christian ethicists' work (see Smit, 2007). The interplay between prayer and politics (or worship and ethics), reflected on by Smit, has a crucial prayer and politics (or worship and ethics), reflected on by Smit, has a crucial the deeply embodied, inter-subjective, multi-sensory and participatory nature of worship in the Christian tradition.

23.See $\mathrm{G}$ Meilaender's work on the social and ethical thought of CS Lewis with the sumptuous title, Taste for the Other (2003).

24.It is important to emphasise here that carnal hermeneutics sees 'touch' as an intelligent sense, capable of discrimination and discernment. This means that one can distinguish between 'good touch, which differentiates between various kinds of sense' and 'bad touch, which degenerates into coarse undifferentiated behaviour (gluttony, loutishness, perversion)' (Kearney 2015:23). Kearney is therefore able to speak of an 'immorality of the senses' which is the product of 'contact deprived of tact: grasping without feeling consuming without caressing 'contact deprived of tact. grasping without feeling, consuming without caressing swallowing without tasting, gorging without gustation' (2015:23). The same could be said of 'taste': 'Good taste is delicate, discriminating, integral, free. Bad taste is partial, reductive, unmediated, driven' (2015:23-24). Therefore, the introduction in the quas in the quantity or even intimacy of embodied encounters as such (i.e. more contact), but in the quality of such encounters informed by greater carnal intelligence and sensitivity (i.e. more tact). 
communities to embody the good life: personally, communally, and institutionally. This has important implications for how one might reimagine the congregational praxes of pastoral care, liturgy and homiletics, diaconal ministry, and catechesis.

In coming to the more formally theological implications, I will restrict my final comment to what I propose to explore in my own theological project.

The most obvious place to begin would be with a theology of incarnation. Indeed much has already been done in this regard to restore the value of the body in Christian theological discourse and praxis. However, I am interested in using carnal hermeneutics as a way of reimagining Christ's (bodily) ascension, keeping in mind that it is often here that the carnal character of Christian theology has been betrayed; but also that the ascension is a crucially contested site for ecclesiological and political questions. ${ }^{25}$ A carnal hermeneutic reading of the ascension would emphasise the incarnation as an enduring reality that continues to mark the life of God and the life of those who follow Christ. Through Christ's bodily ascension, 'the Word made flesh' endures beyond our persistent attempts to spiritualise and abstract the incarnated Word beyond recognition, challenging the church (as the body of Christ) to participate in the scandal of particularising the universal: of incarnating the Word in ever changing circumstances and contexts (Manoussakis 2015:307).

At the same time, the ascension of Christ as body illuminates the important ways in which Christ's body is 'not here anymore': absent, beyond reach, hidden. At least in Luke's narrative, the ascension (which in some respects has a phenomenological structure analogous to quiet Saturday) is intricately linked with the Pentecost event and the birth of the church. Christ's absenting creates a space of mourning (Good Friday) and anticipation (Parousia) in which the church is born (Pentecost). As a Eucharistic community, the church is given the imperative to bear witness to Jesus: to remember, in new circumstances and creative ways, the Christ who showed more than any other body what it means to have good taste and to live tactfully; to be attentive, sensitive, and sensible.

Finally, it is important to recall that Christ ascends to be exalted as Lord and Saviour at the right hand of God - from there to judge the living and the dead. Here, it is no longer we who read Christ, but Christ who reads us. As the judgment scene of Matthew 25 so powerfully makes clear, our carnal readings and dealings of each other will themselves be read and ultimately judged by how we responded to...

... the divine itself manifest in 'the least of these': in the colour of their eyes, in the lines of their hands and fingers, in the cracked tone of voice, in all the tiny epiphanies of flesh and blood. (Kearney 2006:7)

25.See Farrow (1999, 2011) and Ward (1999). Both emphasise the corporeal in thei treatment of the ascension, but do so in different ways and arrive at divergent ecclesiological and political conclusions.

\section{Acknowledgements Competing interests}

The author declares that he has no financial or personal relationships which may have inappropriately influenced him in writing this article.

\section{References}

Ackermann, D.M., 2003, After the locusts: Letters from a landscape of faith, Eerdmans, Cambridge.

Coetzee, I., 2014, 'Apology given for "blackface"', Die Matie (Stellenbosch), viewed 03 October 2014, from http://www0.sun.ac.za/diematie/archive/2014/2014-10-22.pdf

David W. Griffith, 1915, Birth of a nation (film), United States.

De Gruchy, J.W., 2000, Seeing things differently, Mercer Books, Cape Town.

Eagleton, T., 2008, Trouble with strangers: A study of ethics, Wiley-Blackwell, Oxford.

Fanon, F., 1967, Black skin, white masks, Pluto Press, London.

Farrow, D., 1999. Ascension and ecclesia: On the significance of the doctrine of the ascension for ecclesiology and Christian cosmology, T\&T Clark, Edinburgh.

Farrow, D., 2011, Ascension theology, T\&T Clark International, London.

Fouché, H. \& Smit, D.J., 1996, 'Initiating a dialogue on “dialogue”', Scriptura 57, 79-102.

Froneman, W., 2012, 'Pleasure beyond the call of duty: Perspectives, retrospectives and speculations on boeremusiek', PhD thesis, Stellenbosch University, Stellenbosch.

Kearney, R., 2002, On Stories, Routledge, London.

Kearney, R., 2003a, Strangers, gods, and monsters: Interpreting otherness, Routledge, London.

Kearney, R., 2003b, 'Narrative and the ethics of remembrance', in J. Morley \& J. Phillips, (eds.), Imagination and its pathologies, pp. 51-63, MIT Press, Cambridge.

Kearney, R., 2006, 'Epiphanies of the everyday: Toward a micro-eschatology', in J.P. Manoussakis, (ed.), After god: Richard Kearney and the religious turn in continental philosophy, pp. 3-20, Fordham University Press, New York.

Kearney, R., 2010a, Anatheism: Returning to god after god, Columbia University Press, New York.

Kearney, R., 2010b, 'Exchanging memories: Between poetics and ethics', in W. Schwarz, (ed.), Memories: Histories, theories, debates, pp. 92-103, Fordham University Press, New York.

Kearney, R., 2011, 'What is diacritical hermeneutics?', Journal of Applied Hermeneutics $1(1), 1-14$

Kearney, R., 2012, 'Diacritical hermeneutics', in M. Portocarrero, L. Umbelino \& A. Wiercinski, (eds.), Hermeneutic Rationality / La rationalite hermeneutique, pp. 177-196, Lit Verlag, Berlin.

Kearney, R., 2013, 'Forgiveness at the limit - Impossible or possible?' in F. O'Rourke (ed.), What happened in and to moral philosophy in the twentieth century? Philosophical essays in honor of Alasdair Macintyre, pp. 304-320, University of Notre Dame Press, Notre Dame.

Kearney, R., 2014, 'Losing our touch', in New York Times, viewed n.d., from http:// opionator.blogs.nytimes.com/2014/08/30/losing-our-touch

Kearney, R., 2015, 'The wager of carnal hermeneutics', in R. Kearney \& B. Treanor (eds.), Carnal hermeneutics, pp. 15-56, Fordham University Press, New York.

Kearney, R. \& Semonovitch, K. (eds.), 2011a, Phenomenologies of the stranger, Fordham University Press, New York.

Kearney, R. \& Semonovitch, K., 2011b, 'At the threshold: Foreigners, strangers, others', in R. Kearney \& K. Semonovitch, (eds.), Phenomenologies of the stranger: Between hostility and hospitality, p. 16, Fordham University Press, New York.

Kristeva, J., 1991, Strangers to ourselves, Columbia University Press, New York.

Manoussakis, J.P., 2015, 'On the flesh of the word', in R. Kearney \& B. Treanor, (eds.), Carnal hermeneutics, pp. 306-315, Fordham University Press, New York.

Meilaender, G., 2003, The taste for the other: The social and ethical thought of CS Lewis, Regent College Publishing, Vancouver.

Meiring, J., 2014, 'Theology in the flesh: Exploring the corporeal turn from a Southern African perspective', Vrije Unversiteit Amsterdam/University of Pretoria, viewed n.d., from http://www.dart-europe.eu/full.php?id=871701

Pretorius, H.M. 2015. 'Theology at the limit: An investigation of Richard Kearney's philosophical hermeneutics in search of a responsible theological hermeneutic', Stellenbosch University, from https://www.academia.edu/10434936/Theology at_the_Limit_An_investigation_of_Richard_Kearney_s_philosophical_ hermeneutics_in_search_of_a_responsible_theological_hermeneutic.

Ricoeur, P., 1986, Fallible Man, Fordham University Press, New York.

Ricoeur P., 1990, Oneself as Another, Chicago University Press, Chicago.

Ricoeur, P., 2004, Memory, History, Forgetting, University of Chicago Press, Chicago.

Smit, D., 2007, '“Seeing things differently" on prayer and politics', in E. Conradie, (ed.), Essays in public theology, pp. 445-454, SUN Press, Stellenbosch.

Smit, D., 2013, 'On Bernard Lategan: Interpretation matters' - An introduction, in R.R. Vosloo, (ed.), Remembering theologians - Doing theology: Collected essays 5, pp. 325-334, SUN Press, Stellenbosch. 
Toadvine, T., 2015, 'Biodiversity and the Diacritics of Life', in R. Kearney \& B. Treanor, (eds.), Carnal hermeneutics, pp. 235-248, Fordham University Press, New York.

Treanor, B., Clingerman, F., Drenthen, M. \& Utsler, D. (eds.), 2013, Interpreting nature: The emerging field of environmental hermeneutics, Fordham University Press, New York.
Treanor, B., 2015, 'Mind the Gap: the Challenge of Matter', in R. Kearney \& B. Treanor, (eds.), Carnal hermeneutics, pp. 57-73, Fordham University Press, New York.

Ward, G., 1999, 'Bodies: The displaced body of Jesus Christ', in J. Milbank, C. Pickstock \& G. Ward, (eds.), Radical orthodoxy, pp. 163-181, Routledge, London. 